\title{
Adrenal Cortical Cell
}

National Cancer Institute

\section{Source}

National Cancer Institute. Adrenal Cortical Cell. NCI Thesaurus. Code C48358.

An endocrine glandular cell located on the surface of the adrenal gland (adrenal cortex). It is responsible for the synthesis of glucocorticoids, aldosterone, and androgens. 